\title{
Effect of virgin coconut oil (VCO) on the physical stability of sweet potato leaf extract (Ipomoea batatas (L.) Lam) creams and antibacterial activity test against Staphylococcus aureus ATCC 25923
}

\author{
Mauritz Pandapotan Marpaung*, Dani Prasetyo \\ Faculty of Pharmacy, University of Kader Bangsa, \\ Jl. Mayjen H.M. Ryacudu No. 88, Seberang Ulu 1, Palembang
}

Submitted: 14-11-2020

Reviewed: 03-01-2021

Accepted: 12-03-2021

\begin{abstract}
VCO (virgin coconut oil) has benefits for skin health such as softening the skin, maintaining skin health, and protecting the skin from radiation and free radicals. VCO as one of the raw materials for making cream preparations can affect its physical stability. This study aimed to analyze the effect of VCO on the physical stability of sweet potato leaf extract creams and antibacterial activity test against Staphylococcus aureus ATCC 25923. The creams were made with five formulas namely base, extract cream $2 \%$, and VCO $1 \%, 3 \%, 5 \%$ added to the extract cream $2 \%$ respectively. Physical stability test included storage for six weeks at room temperature. Stability parameters were organoleptic observation, homogeneity, $\mathrm{pH}$, spreadability, adhesivity, and cream type. Statistical analysis was carried out with the Anova and Kruskal Wallis tests. The organoleptic test results of the cream extract showed a distinctive odor, green color, with semisolid and homogeneous texture. Increasing the concentration of VCO will increase the spreadability of extract cream but did not affect $\mathrm{pH}$ and adhesion. The conclusion of this study was that extract cream $2 \%$ without the addition of VCO was the most stable cream formulation. Besides that, all the cream formulas did not show antibacterial activity against Staphylococcus aureus ATCC 25923.
\end{abstract}

Keywords: sweet potato leaves, cream, VCO, physical test, antibacterial

\section{*Corresponding author:}

Mauritz Pandapotan Marpaung

Faculty of Pharmacy, University of Kader Bangsa

J1 Mayjen H.M. Ryacudu No. 88, Seberang Ulu 1, Palembang

Email: mauritzchem@gmail.com 


\section{INTRODUCTION}

Sweet potato leaves are one part of the plants that are spread evenly throughout Indonesia which is usually used as vegetables. This leaves have health benefits because they contain secondary metabolite compounds such as flavonoids, alkaloids, tannis, and saponins (Susanto et al., 2019). With the presence of these active compounds, these leaves have antibacterial activity against various bacteria, one of which is Staphylococcus aureus (Rangotwat et al., 2016; Osuntokun et al., 2020). This bacterium is a Gram-positive bacterium that can cause skin infection, causing various skin diseases, one of which is acne. Acne is an inflammatory disease of the skin caused by excessive oil gland activity and infection of bacteria (Meilina and Hasanah, 2018). With the presence of these active compounds that act as antibacterials, empirically sweet potato leaves can be used as anti-acne. In addition, with a high antioxidants, these leaves are also useful for preventing wrinkles and pigmentation on the skin (Dipahayu et al., 2014).

To maximize the utilization of the skin, this research formulated cream from sweet potato leaves as the active substance. Selection of cream in this study because it is one of the preparations on the skin that is more stable than lotions with various conditions (Mu'awanah et al., 2014). This preparation also has several advantages such as being easily applied and cleaned with water, not sticky, and evenly distributed on the skin (Ulfa et al., 2020).

The formulation of cream preparation consists of active substances, raw materials, and other additives. In this study, the raw material added to the cream of sweet potato leaf extract was VCO (Virgin Coconut Oil). VCO is oil from fresh coconut fruit that is processed naturally with or without heating, without refining, and adding chemicals. VCO has benefits for the skin such as softening and protecting the skin from radiation and free radical (Hastuti, 2017). The addition of VCO in the cream because it has good properties for the skin, namely emollient and moisturizer which can soften and humidify the skin so that it can reduce its diffusion pressure. Short and medium chain fatty acids such as lauric acid and oleic acid are easily absorbed through the skin so that they can increase the penetration rate of active compounds from cream preparations containing VCO (Setiawan et al., 2019). VCO can be useful as an anti-acne because it can prevent tissue damage, provides a smooth and soft texture to the skin, protection against the skin and contains compounds that act as antibacterials (Mu'awanah et al., 2014). VCO is antibacterial because it contains medium chain faty acids which break down in the body into monoglycerides in the form of monolaurin, monocaprin, monocaprillin and monocaproin which have antibacterial activity such as against Propionibacterium acne, Staphylococcus epidermidis, and Staphylococcus aureus which are the bacteria that cause acne (Margata et al., 2019). Based on the benefits of VCO for skin, with the addition of VCO into the sweet potato leaf extract cream in this study was expected to obtain a cream extract that has a good spread and adhesion, a soft and smooth texture, so that it can be used to prevent and treat disease disorders in the skin, especially caused by Staphylococcus aureus.

To obtain a stable extract cream, a physical stability test is required so that the use of cream is safe to use and avoid things that causes damage to the skin such as irritation, allergies, dark spots and discoloration of the skin (Indriaty et al., 2018). A stable cream is a preparation that has physical properties and characterization that is within acceptable limits during the period of storage and use. The stability of cream is influenced by several factors such as the stability of the active substance, the interaction of the active substance with additives, the temperature of heating in the manufacture additives and raw materials. With the addition of VCO as a raw material can affect the physical stability of any cream extract formula made. Therefore, the aims of this study were to analyze the effect of the addition of VCO on the physical stability of sweet potato extract cream and to test its activity as an antibacterial against Staphylococcus aureus. The physical stability parameters of extract cream carried out in this study consists of organoleptic, homogeneity, $\mathrm{pH}$, spreadability, adhesivity, and cream type tests. 


\section{MATERIALS AND METHOD \\ Materials}

The tools used in this study were rotary evaporator (Ika 10), waterbath (Memmert), magnetic stirrer, analytical balance (BEL), pH meter (ATC 2011), and microscope (Optilab). The materials used were ethanol (Merck), aquadest (Brataco), Dragendorff reagent, Wagner reagent, Mayer reagent, $\mathrm{FeCl}_{3}$ (Pudak Scientific), $\mathrm{NaOH}$ (Merck), $\mathrm{HCl}$ (Merck), DMSO (Merck), chloroform, glacial acetic acid (Emsure), $\mathrm{H}_{2} \mathrm{SO}_{4}$ (Merck), and metylene blue (Science company). The constituent ingredients of cream with a degree of pharmaceathic were triet hanolamin (Making Cosmetics), nipasol (Alpha Chemika), nipagin (AbMole), adeps lanae, stearic acid (Merck), and paraffin (Asian Oil Company).

The sample was sweet potato leaves from Sukadamai Village, Tanjung Lago District, Banyuasin Regency, South Sumatra. The bacterium used for the study was Staphylococcus aureus ATCC 25923 which was obtained from Balai Besar Laboratorium Kesehatan (BBLK), Palembang.

\section{Methods \\ Determination of plant}

The sweet potato plant was carried out the process of identifying plant types through the determination process in the Herbarium Laboratory, Andalas University, Padang.

\section{Sweet potato leaf extraction}

As much as $232 \mathrm{~g}$ of sweet potato leaf simplicia obtained from dry sorting, washing, chopping and refining was extracted by maceration method in ethanol $96 \%$. Then, it was evaporated with a rotary evaporator at a temperature of $60^{\circ} \mathrm{C}$ and over a waterbath. The extract was weighed and the percent yield was determined.

\section{Phytochemical screening}

Flavonoids were present when $2 \mathrm{~mL}$ of extract was put into a test tube and a few drops of $\mathrm{NaOH} 20 \%$ solution were added to produce a yellow color (Ugochukwu et al., 2013). In the test of Alkaloids, $0.5 \mathrm{~g}$ of the extract was added with $1 \mathrm{~mL}$ of $\mathrm{HCl} 2 \mathrm{~N}$ and $9 \mathrm{~mL}$ of distilled water, heated in a waterbath for 2 minutes, cooled and filtered. Then, 3 drops of the filtrate were taken, and then added with 2 drops of Mayer, Wagner, and Dragendorff reagents respectively. The presence of alkaloids showed that the Mayer reagent produced a white/yellow (yellowish white) precipitate, the Dragendorff reagent produced terracotta to orange precipitate, and the Wagner reagent produced a reddish brown precipitate. If at least two results are tested positive, the extract is considered to contain alkaloids (Marjoni, 2016).

With the presence of saponins, the extract produced a stable foam when $2 \mathrm{~mL}$ of the extract was dissolved in $6 \mathrm{~mL}$ of hot distilled water and shaken vigorously for 10 seconds (Ugochukwu et al., 2013). In test of tannin, a blue/dark blue or blackish green color was formed when $0.5 \mathrm{~g}$ of the extract was heated in $10 \mathrm{~mL}$ of distilled water and filtered. The filtrate was diluted with distilled water until it was colorless and added 1-2 drops of $\mathrm{FeCl}_{3} 1 \%$ (Deepa and Padmaja, 2014). In the test of steroid/triterpenoid test, $2 \mathrm{~mL}$ of the tested solution was evaporated in evaporating dish. The residue was dissolved with $0.5 \mathrm{~mL}$ of chloroform and $0.5 \mathrm{~mL}$ of glacial acetic acid. Then, $2 \mathrm{~mL}$ of concentrated sulfuric acid was added through the walls of the test tube. The presence of a brown or violet ring at the border of the solution indicated triterpenoids. If a greenish blue ring was formed, it indicated the presence of steroids (Cahyani et al., 2019).

\section{The making process of cream preparations}

The making process of cream preparations consisted of oil phase and water phase. In the oil phase, stearic acid, liquid paraffin, adeps lanae, and VCO were heated in the evaporating dish at $70^{\circ} \mathrm{C}$ in the water bath until melting. In the water phase, distilled water and triethanolamine were 
heated in the water bath until melting at a temperature of $70^{\circ} \mathrm{C}$. The water phase was poured into the oil phase gradually into a hot mortar. Nipagin and nipasol were added and crushed until homogeneous mass of cream was formed. Then, the extract was added gradually until it was homogeneous according to the formulation in Table 1 (Rahim et al., 2011).

\section{Cream preparation test Organoleptic test}

Physical testing of cream preparations by observing the color, odor, and texture of the formulated cream (Azkiya et al., 2017).

Table 1. Formulation of cream extract preparation of sweet potato leaves

\begin{tabular}{lccccc}
\hline \multicolumn{1}{c}{ Materials } & Formula 1 & Formula 2 & Formula 3 & Formula 4 & Formula 5 \\
\hline Extract $(\mathrm{g})$ & - & 2 & 2 & 2 & 2 \\
VCO $(\mathrm{mL})$ & - & - & 1 & 3 & 5 \\
Stearic acid $(\mathrm{g})$ & 14.5 & 14.5 & 14.5 & 14.5 & 14.5 \\
Triet hanolamin $(\mathrm{mL})$ & 1.5 & 1.5 & 1.5 & 1.5 & 1.5 \\
Adeps lanae $(\mathrm{g})$ & 3 & 3 & 3 & 3 & 3 \\
Paraffin Liquid $(\mathrm{mL})$ & 5 & 5 & 5 & 5 & 5 \\
Nipagin $(\mathrm{g})$ & 0.14 & 0.14 & 0.14 & 0.14 & 0.14 \\
Nipasol $(\mathrm{g})$ & 0.05 & 0.05 & 0.05 & 0.05 & 0.05 \\
Aquadest $(\mathrm{mL}) \mathrm{ad}$ & 100 & 100 & 100 & 100 & 100 \\
\hline
\end{tabular}

\section{Homogeneity test}

Applying $1 \mathrm{~g}$ of top, middle, and bottom parts of cream preparation on a glass object and observing it under the light to determine whether the particles are lumpy or not completely mixed. If there was no such particles present, the sample was homogeneus (Azkiya et al., 2017).

\section{pH test}

One gram of cream sample was dissolved in $10 \mathrm{ml}$ distilled water. It was stirred homogeneusly and let stand until settled. The $\mathrm{pH}$ of the water in the mixture was measured by replication three times (Azkiya et al., 2017).

\section{Spreadability test}

As much as $0.5 \mathrm{~g}$ of the preparation was placed on a round glass with a scale. Then it was covered with a round glass that had been weighed and its weight was known in five minutes. After that, the spreading diameter was recorded. Next, material weighing $50 \mathrm{~g}$ was added for a minute and the diameter of the spread was recorded. After that a load of $50 \mathrm{~g}$ to $200 \mathrm{~g}$ was added to determine the effect of the load on the diameter of cream spreadability and the diameter of the distribution was recorded (Arbie et al., 2020).

\section{Adhesivity test}

As much as $0.5 \mathrm{~g}$ was placed on a glass object with certain width. Then it was covered with another glass object and pressed with a load of $1 \mathrm{~kg}$ for five minutes. The glass object was installed with a load of $80 \mathrm{~g}$ and the time it took to separate the two objects was recorded. The repetition was carried out for three times.

\section{Cream type test}

A total of 1 drop of methylene blue solution was given in $0.1 \mathrm{~g}$ of the cream preparation. Then the methylene blue color distribution was observed under the microscope. If the color spread 
evenly on the preparation, the type of cream was oil in water $(\mathrm{o} / \mathrm{w})$. If the color is in the form of spots, the type of cream formed was water in oil (w/o) (Elmitra and Rikomah, 2018).

\section{Stability test}

The stability test was carried out for 6 weeks at room temperature. Every week for 6 weeks, observation were made on the physical changes of the cream such as organoleptic, homogeneity, pH, spreadability, and adhesion (Shovyana and Zulkarnain, 2013).

\section{Antibacterial activity test}

To find out the extract and VCO without the form of the cream has an antibacterial effect on Staphylococcus aureus ATCC 25923 then carried out measurements of inhibition diameter against the tested bacteria. This is done to explain the results to be obtained from antibacterial activity test of extract cream with and without the addition of VCO to the tested bacteria. The extract and VCO were made with the respective concentrations of $1 \%, 3 \%, 5 \%, 7 \%, 9 \%, 10 \%, 20 \%, 40 \%, 60 \%$, $80 \%$, and $100 \%$. Inhibition test of extracts, VCO, and cream extract preparations against tested bacteria was carried out using the agar diffusion method through Mueller Hinton Agar (MHA) media. The positive control used was Penicillin $G$. The test results were in the form of measurement of inhibition diameter using a caliper which was marked by a clear zone on the disc paper.

\section{Data Analysis}

The data obtained was the result of physical stability test of cream preparation with the addition of VCO presented in a table and then analysed by using statistical test.

\section{RESULT AND DISCUSSION}

The results of plant determination showed that the plants tested were sweet potato and the type was Ipomoea batatas (L.) Lam. Determination is the process of determining the type of plant to be used based on plant morphology with known identities so as to avoid errors in sampling (Darma and Marpaung, 2020). The simplicia of sweet potato leaves obtained from various processes such as dry sorting, washing, chopping, and refining was aimed to facilitate extraction of active substances in the form of secondary metabolites contained in the extract.

The extraction method used was maceration by immersing the simplicia in ethanol $96 \%$ at room temperature with several stirring times. In the maceration process, the active substance was withdrawn by certain organic solvents until there was a concentration balance of the solution inside and outside the cell. This method has several advantages such as being easy to operate, able to extract thermolable active substances, easy to obtain tools and materials, and relatively cheap operating costs (Farah et al., 2019). The extraction resulted in the form of thick extract with a weight of $27.085 \mathrm{~g}$ produced a yield of $11.67 \%$. The yield was the weight ratio of the extracted extract to the weight of the extracted simplicia. The yield showed the number of active substances in the extract. The greater the yield value, the more content of active substance present in the extract (Hasnaeni et al., 2019). 


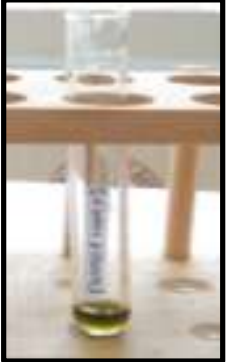

(a)

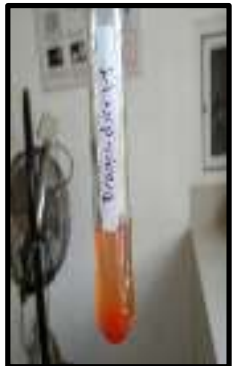

(b)

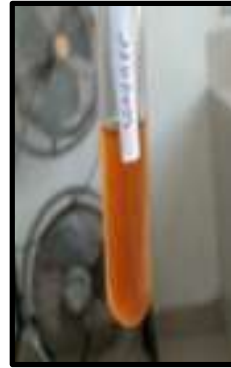

(c)

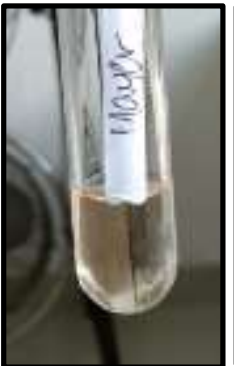

(d)

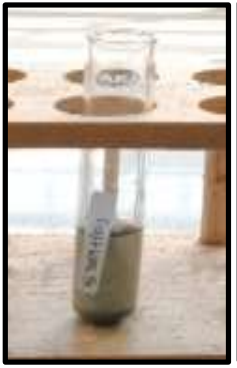

(e)

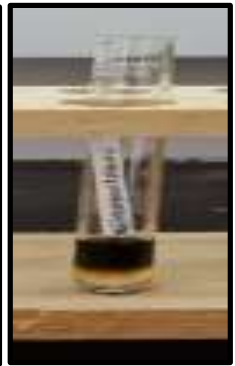

(f)

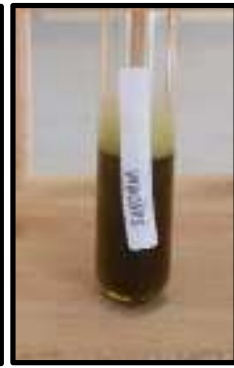

(g)

Figure 1. Results of phytochemical test that identify flavonoid (a); alkaloids by Dragendorff (b), Wagner (c), and Mayer reagent (d); tannins (e); triterpenoids (f); and saponins (g)

The phytochemical test results showed that qualitatively sweet potato leaf extract contained secondary metabolites in the form of flavonoids, alkaloids, saponins, tannins, and triterpenoids (Figure 1). This was in accordance with the results of research that sweet potato leaves contained alkaloids, flavonoids, tannins, and saponins compounds (Susanto et al., 2019; Lalu et al., 2017). With the presence of these secondary metabolite compounds, sweet potato leaf extract has the potential as an antibacterial natural ingredient. Secondary metabolite compounds in the form of flavonoids, alkaloids, saponins, tannins, triterpenoids, steroids, glycosides, and phenolics have a role that can inhibit the growth of Gram-positive and Gram-negative bacteria (Nomer et al., 2019).

To determine the physical quality of the cream preparation extract with the addition of VCO, a stability test was carried out every week for six weeks which included organoleptic, homogeneity, $\mathrm{pH}$, spreadability, adhesivity, and cream type test. The organoleptic test results of the cream extract showed a distinctive odor, green color, with a semisolid texture every week for six weeks. The organoleptic test was carried out to determine the physical picture of the cream through the color, odor and texture of the preparation during storage. Every week for six weeks, all the cream formulas did not change color, smell, and texture so that they met the stability test standards. In the homogeneity test, all the cream formulas showed homogeneous properties with no bubble particles found on the preparation every week for six weeks (Table 2). The aim of the homogeneity test was to determine the distribution of the particles of the preparation. The homogeneity test could also determine if the mixture between the cream basic ingredients and the extract were distributed evenly.

Table 2. Organoleptic \& homogeneity test result of sweet potato leave extract cream for six weeks

\begin{tabular}{llccc}
\hline \multicolumn{1}{c}{ Cream Formula } & Colors & Odor & Texture & Homogeneity \\
\hline Base & White & None & Semisolid & Homogenous \\
Extract 2\% & Green & Distinctive & Semisolid & Homogenous \\
Extract 2\%+VCO 1\% & Green & Distinctive & Semisolid & Homogenous \\
Extract 2\%+VCO 3\% & Green & Distinctive & Semisolid & Homogenous \\
Extract 2\%+VCO 5\% & Green & Distinctive & Semisolid & Homogenous \\
\hline
\end{tabular}

The $\mathrm{pH}$ test was determined to regulate the acidity level of the cream extract preparation so that the resulting cream was safe to apply and would not cause skin irritation at the time of use. The 
$\mathrm{pH}$ range value of the cream extract with the addition of VCO was 6.96-7.8. The $\mathrm{pH}$ value requirements according to SNI 16-4399-1996 were 4.5-8. Acidic cream preparations would irritate the skin and alkaline creams would cause the skin to become dry and scaly (Lumentut et al., 2020). The $\mathrm{pH}$ test results from week 0 to week 6 showed that all cream extract met SNI standards (Table 3). Therefore, all cream extract were safe to apply on the skin surface. With sig. value of 0.497 (p.value > 0.05) in the Anova test results showed that there was no significant difference between the $\mathrm{pH}$ value and the addition of VCO in the cream extract formula.

Table 3. pH test result of cream extract of sweet potato leaves

\begin{tabular}{lccccccc}
\hline \multicolumn{1}{c}{ Cream } & \multicolumn{7}{c}{$\mathbf{p H}$ value on week ... } \\
\cline { 2 - 8 } Formula & $\mathbf{0}$ & $\mathbf{1}$ & $\mathbf{2}$ & $\mathbf{3}$ & $\mathbf{4}$ & $\mathbf{5}$ & $\mathbf{6}$ \\
\hline Base & $7.6 \pm 0.14$ & $7.6 \pm 0.28$ & $7.13 \pm 0.01$ & $7.26 \pm 0.10$ & $7.30 \pm 0.07$ & $7.26 \pm 0.04$ & $7.23 \pm 0.16$ \\
Extract 2\% & $7.4 \pm 0.07$ & $7.3 \pm 0.21$ & $7.00 \pm 0.35$ & $7.10+0.22$ & $7.00 \pm 0.57$ & $7.06 \pm 0.05$ & $7.16 \pm 0.02$ \\
Extract 2\%+ & $7.8 \pm 0.07$ & $7.1 \pm 0.28$ & $6.90 \pm 0.14$ & $7.13 \pm 0.04$ & $6.96 \pm 0.03$ & $7.10 \pm 0.28$ & $7.13 \pm 0.23$ \\
VCO 1\% & & & & & & \\
Extract 2\%+ & $7.8 \pm 0.14$ & $7.0 \pm 0.35$ & $6.80 \pm 0.28$ & $7.16 \pm 0.11$ & $6.96 \pm 0.16$ & $7.16 \pm 0.11$ & $7.20 \pm 0.35$ \\
VCO 3\% & & & & & & & \\
Extract 2\% + & $7.6 \pm 0.21$ & $7.1 \pm 0.14$ & $6.96 \pm 0.04$ & $7.00 \pm 0.42$ & $7.03 \pm 0.02$ & $7.13 \pm 0.09$ & $7.13 \pm 0.45$ \\
VCO 5\% & & & & & & & \\
\hline
\end{tabular}

The spreadability test aimed to determine the ability of the cream extract preparations to spread on the skin. The greater the spreadability value, the easier for the cream preparation to be spread evenly on the skin surface. In Table 4, the highest spreadability was found in the cream extract $2 \%$ preparation. With the addition of $\mathrm{VCO}$, the value of the spreadability of the cream was getting smaller as the VCO concentration was added. This showed that the water content as a constituent ingredient of the cream was decreasing so that the formulation was denser. On the cream basis, during this test at week 0 to week 6 there was a decrease in the spreadability while when added with the extract there was an increase in spreadability. The addition of VCO to the cream extract showed a tendency to decrease the spreadability until week 6.

Table 4. Results of spreadability test of sweet potato leaves extract cream

\begin{tabular}{|c|c|c|c|c|c|c|c|}
\hline \multirow{2}{*}{$\begin{array}{c}\text { Cream } \\
\text { formula }\end{array}$} & \multicolumn{7}{|c|}{ Spreadability in week ... (cm) } \\
\hline & 0 & 1 & 2 & 3 & 4 & 5 & 6 \\
\hline Base & $8.0 \pm 0.71$ & $8.1 \pm 1.27$ & $7.37 \pm 0.94$ & $6.9 \pm 0.71$ & $6.4 \pm 0.28$ & $6.4 \pm 0.92$ & $6.55 \pm 0.83$ \\
\hline Extract $2 \%$ & $9.4 \pm 0.85$ & $8.8 \pm 1.70$ & $9.1 \pm 0.88$ & $8.4 \pm 0.14$ & $8.4 \pm 0.85$ & $8.5 \pm 0.85$ & $8.7 \pm 1.13$ \\
\hline $\begin{array}{l}\text { Extract } 2 \%+ \\
\text { VCO } 1 \%\end{array}$ & $9.03 \pm 0.75$ & $8.4 \pm 1.56$ & $8.7 \pm 0.85$ & $9.2 \pm 0.35$ & $8.1 \pm 0.49$ & $8.03 \pm 0.72$ & $8.15 \pm 0.76$ \\
\hline $\begin{array}{l}\text { Extract } 2 \%+ \\
\text { VCO } 3 \%\end{array}$ & $8.8 \pm 1.48$ & $8.35 \pm 0.67$ & $8.7 \pm 1.13$ & $7.9 \pm 1.41$ & $8.7 \pm 0.64$ & $8.5 \pm 0.99$ & $8.08 \pm 0.04$ \\
\hline $\begin{array}{l}\text { Extract } 2 \%+ \\
\text { VCO } 5 \%\end{array}$ & $6.7 \pm 2.12$ & $8.97 \pm 2.12$ & $8.5 \pm 0.57$ & $8.3 \pm 0.21$ & $8.5 \pm 1.91$ & $7.25 \pm 2.19$ & $7.63 \pm 1.07$ \\
\hline
\end{tabular}

To determine the effect of the addition of VCO on the spreadability of the cream extract, data analysis was carried out through Anova. Anova test results showed a value of sig. 0.00 (sig < 0.05 ). This showed that there was a significant difference in the spreadability after the addition of VCO to the cream extract. The post hoc test through Scheffe was carried out to find out whether there was a significant difference in value between treatment groups. The test results showed that there was no significant difference between base cream and cream extract with the addition of VCO $3 \%$ and 5\%. There was no significant difference between cream extract and cream extract with the addition of VCO $1 \%$. While the extract cream and extract cream with the addition of VCO $1 \%$ had significant differences to the base cream, extract cream with VCO 3\%, and extract cream with VCO 5\%. The significant difference was present if the sig value $<0.05$. 
The adhesivity test aimed to determine the ability of cream preparations to adhere to the skin surface when applied. The longer the cream adhered to the skin, the more increased the active substances of the cream were. Base adhesion was also related to the comfort of applying the base and the length of contact between the base and the skin. A good base was able to guarantee an effective contact time with the skin so that the goal could be achieved (Shovyana and Zulkarnain, 2013).

Table 5. Results of adhesivity test of sweet potato leaves cream extract

\begin{tabular}{|c|c|c|c|c|c|c|c|}
\hline \multirow{2}{*}{$\begin{array}{c}\text { Cream } \\
\text { Formula }\end{array}$} & \multicolumn{7}{|c|}{ Adhesivity in week ...(seconds) } \\
\hline & $\mathbf{0}$ & 1 & 2 & 3 & 4 & 5 & 6 \\
\hline Base & $2.42 \pm 0.52$ & $4.49 \pm 1.34$ & $3.43 \pm 0.53$ & $3.91 \pm 1.20$ & $2.86 \pm 0.46$ & $1.93 \pm 1.2$ & $4.72 \pm 0.51$ \\
\hline Extract $2 \%$ & $3.17 \pm 0.80$ & $6.41 \pm 3.98$ & $.9 \pm 1.27$ & $9.17 \pm 2.33$ & $3.80 \pm 1.35$ & $1.74 \pm 0.27$ & $6.32 \pm 1.62$ \\
\hline $\begin{array}{l}\text { Extract } 2 \%+ \\
\text { VCO } 1 \%\end{array}$ & $3.71 \pm 1.04$ & $4.56 \pm 1.47$ & $7.49 \pm 6.73$ & $5.82 \pm 3.05$ & $3.48 \pm 1.30$ & $3.3 \pm 0.25$ & $6.53 \pm 1.30$ \\
\hline $\begin{array}{l}\text { Extract } 2 \%+ \\
\text { VCO } 3 \%\end{array}$ & $11.07 \pm 3.36$ & $4.49 \pm 0.74$ & $6.73 \pm 3.10$ & $3.21 \pm 0.56$ & $2.32 \pm 0.58$ & $3.86 \pm 2.15$ & $7.41 \pm 0.73$ \\
\hline $\begin{array}{l}\text { Extract } 2 \%+ \\
\text { VCO } 5 \%\end{array}$ & $3.75 \pm 0.38$ & $3.64 \pm 0.60$ & $3.3 \pm 0.62$ & $3.35 \pm 0.61$ & $2.72 \pm 0.85$ & $3.68 \pm 0.71$ & $6.96 \pm 0.51$ \\
\hline
\end{tabular}

The adhesion requirement for topical preparations was more than 4 seconds (Li et al., 2009). On the Table 5 showed the results of adhesivity test before the cycling test at week 0 , only extract cream $2 \%+$ VCO $3 \%$ met these requirements was $11.07 \pm 3.36$ seconds. During the test at week 1 , only extract cream $2 \%+\mathrm{VCO} 5 \%$ did not meet the adhesion requirements while the highest was found in the extract cream $2 \%$ which was $6.41 \pm 3.98$ seconds. In week 2 , the formula that met the adhesion requirement were extract cream $2 \%$, extract cream $2 \%+\mathrm{VCO} 1 \%$, and extract cream $2 \%$ $+\mathrm{VCO} 3 \%$ respectively which is $5.9 \pm 1.27$ seconds; $7.49 \pm 6.73$ seconds; and $6.73 \pm 3.10$ seconds. At week 3 , the formula that met the adhesions were cream extract $2 \%$ and cream extract $2 \%+$ VCO $1 \%$ respectively of $9.17 \pm 2.33$ seconds and $5.82 \pm 3.05$ seconds. At week 4 and 5 none of them met the adhesion requirement. At week 6 , basic cream and all extract creams met the adhesion requirement and the highest was extract cream $2 \%+\mathrm{VCO} 3 \%$ which was $7.41 \pm 0.73$ seconds. From these results, it showed that extract $2 \%$, extract cream $2 \%+\mathrm{VCO} 1 \%$ and extract cream $2 \%$ $+\mathrm{VCO} 3 \%$ often met the adhesion requirement of the cream. The value of the cream adhesiveness test had a significant correlation with the spreadability of the cream, in which the smaller the spreadability of the cream, the longer the time for the cream to adhere and vice versa the greater the spreadability of the cream, the faster the time for the cream to adhere due to the thick consistency of the cream (Lumentut et al., 2020).

Statistical analysis through the Kruskal Wallis nonparametric test was conducted to determine the difference in the influence of adhesion on the extract cream formulations. The results of the analysis showed a significance value of 0.232. This showed that there was not significant difference between the addition of VCO to the physical stability of extract cream on the adhesion $(\operatorname{sig}<0.05)$.

In the cream type test from week 0 to week 6 , it showed that the whole cream extract was evenly distributed. This showed that the entire cream formula had oil-in-water $(\mathrm{o} / \mathrm{w})$ type. This results is strenghthened by the number of water phases as more dispersion of the oil/fat phase as the dispersed phase so that the oil phase will be evenly dispersed into the water phase and form an emulsion of the oil in water with the help of an emulgator (Nonci et al., 2016). The oil-in-water type had several advantages including better spreadability, slowing down the drying process of the skin, and causing less irritation to the skin than water-in-oil types (Arbie et al., 2020). The type of oil-in-water $(\mathrm{o} / \mathrm{w})$ cream used emulsifiers such as triethanolamine, sodium stearate, potassium stearate or ammonium while the water-in-oil (w/o) type used an emulsifier in the form of polyvalent soap, span, and cera. The use of triethanolamine as an anionic emulgator will form a 
very stable o/w emulsion when combined with the appropriate free fatty acids such as stearic acid because it does not undergo discoloration such as oleic acid (Saryanti et al., 2019). Cream with combination of the use of triethanolamine and stearic acid as emulsifiers were stable during the storage period (Cahyati et al., 2015).

Cream preparations that have been tested for physical stability such as organoleptic, homogeneity, $\mathrm{pH}$, spreadability, adhesivity, and type of cream can be said to be good in accordance with existing requirements. The formulation of extract cream have been made with addition of variations in VCO concentration is able to influence the physical stability of cream. The formula that best met the requirements was an extract cream $2 \%$ without the addition of VCO because it had a homogeneous texture, $\mathrm{pH}$ and adhesion met to the requirements and the widest spreadability.

On the antibacterial activity test, the cream base, extract cream $2 \%$ with and without the addition of VCO showed that the overall cream formula did not show inhibition zone against Staphylococcus aureus 25923. This is in accordance with the preliminary test results of determining the inhibition zone of pure extract and pure VCO against tested bacteria with the same concentration, namely $1 \%, 3 \%, 5 \%, 7 \%, 9 \%, 10 \%, 20 \%, 40 \%, 60 \%, 80 \%$, and $100 \%$. In the VCO test results against the tested bacteria showed the overall concentration did not form an inhibitory respone zone. This illustrated that VCO was not effective in vitro in inhibiting the growth of Staphylococcus aureus ATCC 25923 bacteria. Based on the results of study Zulkarnain and Ferdiana (2020) showed VCO with various methods of manufacturing did not have an inhibition zone against Staphylococcus aureus bacteria. VCO with triglyceride content would break down in the body into diglycerides, monoglycerides and free fatty acids. This was what made VCO active as an antibacterial. Fatty acids in VCO that had antibacterial properties were lauric acid, capric acid, and monoglycerides, especially monolaurin and monocaprin (Widiayanti, 2015).

In the test results of the pure extract showed inhibition zone at concentrations of $80 \%$ and $100 \%$ with inhibition diameter of $0.7 \mathrm{~mm}$ and $2.3 \mathrm{~mm}$, respectively. This showed that the pure extract had a weak inhibitory effect against the tested bacteria. Based on the preliminary test results, extract cream $2 \%$ with and without the addition of VCO had no antibacterial activity because the pure extract had inhibition zone at concentration $80 \%$ and $100 \%$. In addition, with extract $80 \%$ and $100 \%$ that had inhibition zone against tested bacteria did not effectively formulate as extract cream. This is because a cream formulation should contain water no less than $60 \%$.

\section{CONCLUSION}

Variations of VCO concentration in the formulation of cream preparations for sweet popato leaf extract have an influence on the physical stability of the cream which includes $\mathrm{pH}$, spreadibility, and adhesion. The most eligible cream formulation was an extract cream $2 \%$ without the addition of VCO. In the antibacterial activity test, there was no inhibition zone in all formulations of cream against Staphylococcus aureus ATCC 25923.

\section{ACKNOWLEDGEMENT}

The author would like to convey his gratitude to the Ministry of Education and Culture for the Junior Lecture Research grant in 2020. The author would also like to convey his sincere gratitude to University of Kader Bangsa in Pharmacy Laboratory and the Balai Besar Laboratorium Kesehatan (BBLK) Palembang for providing research facilities and infrastructure.

\section{REFERENCES}

Arbie, S., Sugihartini, N., \& Wahyuningsih, I. (2020). Formulasi krim M/A dengan variasi konsentrasi ekstrak buah pepaya (Carica papaya L.) menggunakan emulgator asam stearat dan rrietanolamin. Media Farmasi, 16(1), 97-104. https://doi.org/https://doi.org/10.32382/mf.v16i1.1420 
Azkiya, Z., Ariyani, H., \& Setia Nugraha, T. (2017). Evaluasi sifat fisik krim ekstrak jahe merah (Zingiber officinale Rosc. var. rubrum) sebagai anti nyeri. Current Pharmaccutica Sciences, $1(1), 12-18$.

Cahyani, N. P. S. E., Susiarni, J., Dewi, K. C. S., Melyandari, N. L. P., Putra, K. W. A., \& Swastini, D. A. (2019). Karakteristik dan skrining fitokimia ekstrak etanol 70\% batang Kepuh (Sterculia foetida L.). Jurnal Kimia, 13(1), 22-28. https://doi.org/10.24843/jchem.2019.v13.i01.p04

Cahyati, A. N., Ekowati, D., \& Harjanti, R. (2015). Optimasi kombinasi asam stearat dan trietanolamin dalam formula krim ekstrak daun Legetan sebagai antioksidan secara Simplex Lattice Design. Jurnal Farmasi Indonesia, 12(1), 60-69.

Darma, W., \& Marpaung, M. P. (2020). Analisis jenis dan kadar saponin ekstrak akar kuning (Fibraurea chloroleuca Miers) secara gravimetri. Dalton: Jurnal Pendidikan Kimia Dan ..., 3(1), 51-59. https://ojs.uniska-bjm.ac.id/index.php/daltonjurnal/article/view/3109

Deepa, M., \& Padmaja, C. K. (2014). Preliminary phytochemical analysis and thin layer chromatography of the extracts of excoecaria Agallocha L. International Journal of Pharmaceutical Sciences and Research, 5(10), 4535-4542.

Dipahayu, D., Soeratri, W., \& Agil, M. (2014). Formulasi krim antioksidan ekstrak etanol daun ubi jalar ungu (Ipomoea batatas (L.) Lamk) sebagai anti aging. Pharmaceutical Sciences and Research, 1(3), 166-179. https://doi.org/10.7454/psr.v1i3.3485

Elmitra, E., \& Rikomah, S. E. (2018). Formulasi sediaan krim ekstrak etanol daun puding hitam (Graptophyllum Pictum (L.) Griff). Jurnal Katalisator, 3(1), 43-52. https://doi.org/10.22216/jk.v3i1.2297

Farah, J., Yuliar, \& Marpaung, M. P. (2019). Ekstrak etil asetat daun jambu biji merah (Psidium guajava L.) sebagai antioksidan secara in vitro. JFL : Jurnal Farmasi Lampung, 8(2), 78-86. https://doi.org/10.37090/jfl.v8i2.143

Hasnaeni, H., Usman, S., \& Wisdawati, W. (2019). Pengaruh metode ekstraksi terhadap rendemen dan kadar fenolik ekstrak tanaman kayu Beta-beta (Lunasia amara Blanco). Jurnal Farmasi Galenika (Galenika Journal of Pharmacy), 5(12), 175-182. https://doi.org/10.22487/j24428744.0.v0.i0.13599

Hastuti, S. (2017). Pengaruh pemberian VCO ( Virgin Coconut Oil ) terhadap stabilitas salep ekstrak etil asetat daun Seligi ( Phyllanthus buxifolius Muell . Arg ). Indonesian Journal On Medicine Science, 4(2), 157-163.

Indriaty, S., Hidayati, N. R., \& Bachtiar, A. (2018). Bahaya kosmetika pemutih yang mengandung merkuri dan hidroquinon serta pelatihan pengecekan registrasi kosmetika di rumah sakit gunung Jati Cirebon. Jurnal Surya Masyarakat, 1(1), 8-11. https://doi.org/10.26714/jsm.1.1.2018.8-11

Lalu, M. G., Nursamsiar, M, L., \& Gani, S. A. (2017). Sunscreen Activiting of Purple Sweet Potato (Ipomoea batatas L.) Using Spectrofotometry Method. Journal of Pharmaceutical and Medicial Sciences, 2(1), 27-31.

Li, Z., Xie, D., Sun, Z., Zhang, D. H., Lin, S. Y., \& Guo, H. (2009). NH (X3 б) +H/D (S2) $\rightarrow$ h $(\mathrm{S} 2)+\mathrm{NH} / \mathrm{ND}(\mathrm{X} 3 \sigma)$ exchange reactions: State-to-state quantum scattering and applicability of statistical model. Journal of Chemical Physics, 131(12), 192-201. https://doi.org/10.1063/1.3241134

Lumentut, N., Edy, H. J., \& Rumondor, E. M. (2020). Formulasi dan uji stabilitas fisik sediaan krim ekstrak etanol kulit buah pisang Goroho (Musa acuminafe L.) konsentrasi 12.5\% sebagai tabir surya. Jurnal MIPA, 9(2), 42-46. https://doi.org/10.35799/jmuo.9.2.2020.28248

Margata, L., Silalahi, J., Harahap, U., Suryanto, D., \& Satria, D. (2019). The antibacterial effect of enzymatic hydrolyzed virgin coconut oil on Propionibacterium acne, Bacillus subtilis, 
Staphylococcus epidermidis and methicillin-resistant Staphylococcus aureus. Rasayan Journal of Chemistry, 12(2), 987-993. https://doi.org/10.31788/RJC.2019.1225113

Marjoni, M. R. (2016). Dasar-dasar fitokimia untuk diploma III farmasi. Trans Info Media.

Meilina, N. E., \& Hasanah, N. A. (2018). Review artikel: Aktivitas antibakteri ekstrak kulit Manggis (Garcinia mangostana L.) terhadap bakteri penyebab jerawat. Jurnal Farmaka, 16(2), 322-328.

Mu'awanah, I., Setiaji, B., \& Syoufian, A. (2014). Pengaruh Konsentrasi Virgin Coconut Oil (VCO) Terhadap Stabilitas Emulsi Kosmetik dan Nilai Sun Protection Factor (SPF). BIMIPA, 24(1), 1-11. https://doi.org/10.30595/pji.v13i02.1256 10.30595/pji.

Nomer, N. M. G. R., Duniaji, A. S., \& Nocianitri, K. A. (2019). Kandungan senyawa flavonoid dan antosianin esktrak kayu secang (Caesalpinia sappan L.) serta aktivitas antibakteri terhadap Vibrio cholerae. Jurnal Ilmu Dan Teknologi Pangan (ITEPA), 8(2), 216-225. https://doi.org/10.24843/itepa.2019.v08.i02.p12

Nonci, F. Y., Tahar, N., \& Aini, Q. (2016). Formulasi dan uji stabilitas fisik krim susu Kuda Sumbawa dengan Emulgator Nonionik dan Anionik. Jurnal Farmasi UIN Alauddin Makassar, 4(4), 169-178.

Osuntokun, O. T., Yusuf-Babatunde, M. A., \& Fasila, Oladele, O. (2020). Components and Bioactivity of Ipomoea batatas (L.) (Sweet Potato) Ethanolic Leaf Extract. Asian Journal of Advanced Research and Reports, 10(1), 10-26. https://doi.org/10.9734/ajarr/2020/v10i130232

Rahim, F., Aria, M., \& Aji, N. P. (2011). Formulasi krim ekstrak etanol daun Ubi Jalar (Ipomoeae batatas L.) untuk pengobatan luka bakar. Scientia: Jurnal Farmasi Dan Kesehatan, 1(1), 21-26. https://doi.org/10.36434/scientia.v1i1.12

Rangotwat, A., YamLean, P. V. ., \& Lolo, Wi. A. (2016). Formulasi dan uji antibakteri sediaan losio ekstrak metanol daun ubi jalar ungu (Ipomoea batatas POIR) terhadap bakteri Staphylococcus aureus. Pharmacon, 5(4), 90-98. https://doi.org/10.35799/pha.5.2016.13978

Saryanti, D., Setiawan, I., \& Safitri, R. A. (2019). Optimasi formula sediaan krim M/A dari ekstrak kulit pisang kepok (Musa acuminata L.). Jurnal Riset Kefarmasian Indonesia, 1(3), 225-237. https://doi.org/https://doi.org/10.33759/jrki.vli3

Setiawan, A., Ayatri, R. D., Niswantari, N., \& Rusli, N. (2019). Penggunaan emulgator VCO (Virgin Coconut Oil) dalam sediaan krim transdermal asetosal. Warta Farmasi, 8(2), 81-90. https://doi.org/10.46356/wfarmasi.v8i2.120

Shovyana and Zulkarnain. (2013). Stabilitas fisik dan aktivitas krim W/O ekstrak etanolik buah mahkota dewa (Phaleria macrocarph(scheff.) Boerl) sebagai tabir surya. Trad. Med. J, 18(2), 110.

Susanto, A., Hardani, \& Rahmawati, S. (2019). Uji skrining fitokimia ekstrak etanol daun ubi jalar ungu (Ipomoea Batatas L). ARTERI: Jurnal Ilmu Kesehatan, 1(1), 1-7. https://doi.org/10.37148/arteri.v1i1.1

Ugochukwu, S. C., I., A. U., \& Ifeanyi, O. (2013). Preliminary phytochemical screening of different solvent extracts of stem bark and roots of Dennetia tripetala. Asian Journal of Plant Science and Research, 3(3), 10-13.

Ulfa, A. M., Marcellia, S., \& Rositasari, E. (2020). Efektivitas formulasi krim ekstrak kulit jeruk nipis (Citrus aurantifolia-pericappium) sebagai pengobatan luka sayat stadium II pada tikus putih (Rattus novergicus) galur wistar. Jurnal Farmasi Malahayati (JFM), 3(1), 42-52. http://www.ejurnalmalahayati.ac.id/index.php/farmasi/article/view/2434

Widiayanti, A. R. (2015). Pemanfaatan kelapa menjadi VCO (Virgin Coconut Oil) sebagai antibiotik kesehatan dalam upaya mendukung visi Indonesia sehat 2015. Prosiding Seminar Nasional Pendidikan Biologi 2015, 577-584.

Zulkarnain, O., \& Ferdiana, S. (2020). Perbedaan metode pembuatan VCO antibakteria terhadap sifat Fisikokimia, dan uji organoleptik, Antibakteri VCO terhadap Bakteri Staphylococcus 
Aureus. Jurnal Gizi, 9(1), 124-130. https://doi.org/10.26714/jg.9.1.2020.124-130 